\title{
Invivo Management of Spot Blotch (Bipolaris sorokiniana) of Wheat (Triticum aestivum L.), using Bio-Agent and Fungicides
}

\author{
Shiv Shankar Patel ${ }^{1 *}$, Shiv Pratap Singh, Sandeep Kumar, \\ Ashwani Kumar Patel and Digvijay Singh
}

Department of Plant Pathology, Narendra Dev University of Agriculture \& Technology, Kumarganj, Faizabad, India

*Corresponding author

Keywords

Bipolaris

sorokiniana, Spot

blotch, Percent

disease incidence,

Pseudomonas

fluorescence,

fungicides, Bio-

agent

Article Info

Accepted:

20 December 2020

Available Online:

10 January 2021

\begin{abstract}
Wheat (Triticum aestivum L.) is a one of the most important cereal crop after rice in the India which have suffers from a no. of devastating diseases caused by the many fungi, bacteria and viruses. Among the fungal diseases spot blotch (Bipolaris sorokiniana) is a most vital disease of wheat in Northern Eastern Plain Zone of India (NEPZ). The disease has causes considerable grain yield loss of the crop ranging from 18-22 percent. The field experiment was done with eleven different treatments including check with combinations of five different fungicides i.e. Propiconazole 25\% EC, Folicure (Tebuconazole $25 \%$ EC), Hexaconazole 5\% EC, Nativo 75 WG (Tebuconazole $50 \%$ + Trifloxystrobin $25 \%$ ) used as foliar spray. However, the fungicide Vitavax Power $75 \mathrm{WP}$ and one bio-agent Pseudomonas fluorescence used as seed treatment for the management of the disease in the year 2017-18. The percent disease incidence (PDI) indicates that $\mathrm{T}_{7}$ (seed treatment with Vitavax Power 75WP @ 2.5g/kg seed with two foliar spray of Propiconazole 25\% EC @ $0.1 \%$ one at boot leaf stage and second after 20 days after first spray) reduced the disease incidence (32.96\%). The 1000 grain weight, yield q/ha, avoidable yield loss and percent increase in yield were also highest in the aforesaid treatment $(41.52 \mathrm{~g}, 38.58 \mathrm{q} / \mathrm{ha}, 19.31 \%$ and $23.93 \%$ ) respectively, as comparison to other treatment combinations.
\end{abstract}

\section{Introduction}

In India, wheat (Triticum aestivum L.) considered as the most important cereal crop after rice, grown on about an area of $(30.90$ million hectare), production of (97.44 million tons), and productivity of $3172.24 \mathrm{~kg} \mathrm{ha}^{-1}$ and covering 12 percent of world production (DES, MoA \& FW, India, 2016-2017). It is also recognized as a world's major cereal crop and staple food of many regions which grown under both irrigated and rainfed conditions. The crop belongs to family Poaceae or Graminiae (Yadawad et al., 2015), at present, three species, namely $T$. aestivum L. (Bread wheat), T. durum Desf. (Macroni or Durum wheat) and T. dicoccum Schrank. (Emmer wheat), are commonly cultivated. However, the crop has been affected by a number of devastating diseases caused by many fungi, 
bacteria, viruses and nematodes in India, only some of them are usually responsible for causing major economic losses of the crop. Among the fungal diseases, spot blotch of wheat caused by Bipolaris sorokiniana (Sacc.) Shoemaker, is a hemi-biotrophic, phytopathogenic fungal pathogen which prevalent in warmer and humid wheat growing regions of world (Joshi et al., 2007). The pathogen usually induced symptoms on the leaf, sheath, and stem (Chand and Joshi, 2003) and becomes severe especially during grain filling stage and cause significant yield loss (Joshi and Chand, 2002). Due to this destructive pathogen, the yield loss was estimated at 18-22 percent in India (Singh and Srivastasa, 1997). The best way to manage the disease is through an integrated disease management approach including crop improvement and need based application of fungicides and bio-agents. Use of fungicides has been common in recent years and is proven useful and economical in the control of spot blotch (Viedma and Kohli, 1998). Triazole group (e.g.-Propiconazole and Tebuconazole) fungicides have proven very effective against spot blotch. Seed treatment with suitable fungicides such as Captan, Mancozeb, Thiram, Pentachloronitrobenzene (PCNB) or Carboxin guazatine plus, Iprodione and Triadimefon are useful in germinating seeds and seedlings from seedlings blight (Mehta, 1993).

Repeated and indiscriminate use of same fungicides often leads to development of fungicide resistance in pathogen (Gangawane, 1997). The variety which is resistant today becomes susceptible in course of time due to development of new physiological races of the same pathogen. Therefore, the objective carrying behind this experiment was to give a suitable integrated disease management module in a manner by which farmers obtain maximum profit from the crop.

\section{Materials and Methods}

A field study was conducted during Rabi season (2017-18), at student's instructional farm Narendra Deva University of Agriculture and Technology, Kumarganj, Faizabad, which is located in the Indogangetic plains of Eastern Uttar Pradesh at latitude $26.47^{0} \mathrm{~N}$, longitude $82.12^{0}$ and altitude of $113 \mathrm{~m}$ above the sea level. Spot blotch susceptible variety Raj 4015 were used to know the efficacy of different fungicides and bio-agent against the disease. The eleven treatments of fungicides and bio-agent including check was laid out in randomized block design (RBD) with three replications. However, the plot size was kept in $2 \times 2 \mathrm{~m}^{2}$ and maintained all recommended agronomic practices to raise a good crop. Four fungicides namely Propiconazole $25 \%$ EC, Folicure (Tebuconazole 25\% EC), Hexaconazole 5\% EC, Nativo 75 WG (Tebuconazole $50 \%+$ Trifloxystrobin $25 \%$ ) were applied in the field as foliar spray in different mode, while one another fungicides i.e. Vitavax Power 75 WP and one bio-agent Pseudomonas fluorescence used as seed treatment. The description of eleven treatments were, $\mathrm{T}_{1}=$ seed treatment with Pseudomonas fluorescence@6g/kg seed, $\mathrm{T}_{2}=$ Seed treatment with Vitavax Power @ $2.5 \mathrm{~g} / \mathrm{kg}$ seed, $\mathrm{T}_{3}=\mathrm{T}_{1}+$ two foliar spray of Propiconazole @ 0.1\% one at boot leaf stage and second after 20 days, $\mathrm{T}_{4}=\mathrm{T}_{1}+$ two foliar spray of Hexaconazole @ $0.1 \%$ one at boot leaf stage and second after 20 days, $\mathrm{T}_{5}=\mathrm{T}_{1}$ +two foliar spray of Folicure @ $0.1 \%$ one at boot leaf stage and second after 20 days, $\mathrm{T}_{6}=$ $\mathrm{T}_{1}+$ two foliar spray of Nativo (Tebuconazole $50 \%$ + Trifloxystrobin $25 \%$ ) @ 0.4\% one at boot leaf stage and second after 20 days, $\mathrm{T}_{7}=$ $\mathrm{T}_{2}+$ two foliar spray of Propiconazole @ $0.1 \%$ one at boot leaf stage and second after 20 days, $\mathrm{T}_{8}=\mathrm{T}_{2}+$ two foliar spray of Hexaconazole @ 0.1\% one at boot leaf stage and second after 20 days, $\mathrm{T}_{9}=\mathrm{T}_{2}+$ two foliar 
spray of Folicure @ $0.1 \%$ one at boot leaf stage and second after 20 days, $\mathrm{T}_{10}=\mathrm{T}_{2}+$ two foliar spray of Nativo @ $0.4 \%$ one at boot leaf stage and second after 20 days and $\mathrm{T}_{11}=$ check. The assessment of the disease was recorded at three different growth stages of the crop (Zadoks, et al., 1974), viz. GS40 (before spray), GS60 (after first spray) and GS77 (after second spray) of fungicides in 10randomly selected tagged plants of each treatment, using the double digit scale (00-99) developed by (Kumar et al., 1998). The per cent disease intensity (PDI), percent increase in yield and avoidable yield loss were also calculated by using the following formula:

Disease intensity $(\%)=\frac{\text { Sum of total numerical rating }}{\text { Total number of leaf examine } \times \text { maximum rating }} \times 100$

Per cent increase in vield $=\frac{\text { Yield in treated plot } \cdot \text { Yield in check plot }}{\text { Y'eld in check } \cdot \text { plot }} \times 100$

Avoidable yield loss $(A Y L)=\frac{Y P-Y U}{Y P} \times 100$

Where,

$\mathrm{YP}=$ yield under protected condition $\mathrm{YU}=$ yield under unprotected condition

\section{Statistical analysis}

The statistical analysis of field experiment was done by the method randomized block design (RBD).The significance of treatment difference was tested by variance ratio test at 5 per cent level of probability. Correlations were worked out as per AL-Jiouri et al., (1958).

\section{Results and Discussion}

The results showed that the all treatments reduced the disease severity as evident from the double digit score as well as increased the yield and yield parameters like 1000 grain weight in compression to untreated control. The seed treatment with Vitavax Power 75 WP @ 2.5g/kg seed and bio-agent Pseudomonas fluorescence @ 6g/kg seed have significantly increase the germination of seed in the field, in which Vitavax Power 75 WP was found better to increase the seed germination in compression to $P$. fluorescence. The seedling mortality was also significantly reduced in field in case of treated seed with fungicides. The plant disease intensity (PDI) decreased with the application of different treatment over untreated control. The minimum PDI was recorded $32.96 \%$ in $\mathrm{T}_{7}$ (Seed treatment with Vitavax Power 75 WP @ $2.5 \mathrm{gm} / \mathrm{kg}$ seed +2 foliar sprays of Propiconazole @ 0.1\%, first at boot leaf stage second after 20 days), which was highly significant among all the treatments, followed by $35.93 \%$ under $\mathrm{T}_{9}$ (Seed treatment with Vitavax Power 75 WP @ $2.5 \mathrm{gm} / \mathrm{kg}$ seed + 2 foliar sprays of Folicure @ $0.1 \%$, first at boot leaf stage second after at 20 days).

While the maximum PDI was recorded $76.48 \%$ in $\mathrm{T}_{11}$ (untreated control).It evident from table-2 that have applications of different fungicides have impact on 1000 grain weight and yield qha ${ }^{-1}$ in current study. $\mathrm{T}_{7}$ were found significantly superior among all the treatments as highest 1000 grain weight (41.52g) and yield $\mathrm{qha}^{-1}$ (38.58), followed by the $\mathrm{T}_{9}\left(40.13 \mathrm{~g}\right.$ and $37.75 \mathrm{qha}^{-1}$ respectively). The least seed weight and yield qha $^{-1}$ were recorded with $\mathrm{T}_{11}(35.40 \mathrm{~g}$ and 31.13 , respectively).

The maximum percent increase yield $23.93 \%$ and avoidable yield loss $19.31 \%$ were recorded with $\mathrm{T}_{7}$, followed by the $\mathrm{T}_{9}(21.26 \%$ and $17.53 \%$ respectively), while the minimum percent increase yield $(0.0 \%)$ and avoidable yield loss $(0.0 \%)$ were found in $\mathrm{T}_{11}$. 
Table.1 Effect of fungicides and bio-agent on percent disease intensity (PDI) of spot blotch of wheat cause by Bipolaris sorokiniana

\begin{tabular}{|c|c|c|c|c|}
\hline Treatments & Particular's & $\begin{array}{c}\text { Before } \\
\text { spray } \\
\text { (GS40) }\end{array}$ & $\begin{array}{c}\text { After } \\
\text { first } \\
\text { spray } \\
\text { (GS60) }\end{array}$ & $\begin{array}{c}\text { After } \\
\text { second } \\
\text { spray } \\
\text { (GS77) }\end{array}$ \\
\hline $\mathbf{T}_{1}$ & $\begin{array}{l}\text { Seed treatment with Pseudomonas } \\
\text { fluorescence @ 6g/kg seeds }\end{array}$ & $\begin{array}{c}13.33 \\
(21.40)\end{array}$ & $\begin{array}{c}44.81 \\
(42.00)\end{array}$ & $\begin{array}{r}61.30 \\
(51.50)\end{array}$ \\
\hline $\mathbf{T}_{2}$ & $\begin{array}{l}\text { Seed treatment with Vitavax Power } 75 \\
\text { WP @ } 2.5 \mathrm{~g} / \mathrm{kg} \text { seeds }\end{array}$ & $\begin{array}{c}9.63 \\
(18.06)\end{array}$ & $\begin{array}{l}40.56 \\
(39.54)\end{array}$ & $\begin{array}{c}57.04 \\
(49.02)\end{array}$ \\
\hline $\mathbf{T}_{3}$ & $\begin{array}{l}\mathrm{T}_{1}+\text { Two foliar spray of Propiconazole } \\
\text { @ } 0.1 \% \text { (one at boot leaf stage and } \\
\text { second after } 20 \text { days) }\end{array}$ & $\begin{array}{l}12.78 \\
(20.93)\end{array}$ & $\begin{array}{c}28.52 \\
(32.26)\end{array}$ & $\begin{array}{r}38.89 \\
(38.56)\end{array}$ \\
\hline $\mathbf{T}_{4}$ & $\begin{array}{l}\mathrm{T}_{1}+\text { Two foliar spray of Hexaconazole } \\
\text { @ } 0.1 \% \text { (one at boot leaf stage and } \\
\text { second after } 20 \text { days) }\end{array}$ & $\begin{array}{c}12.96 \\
(21.08)\end{array}$ & $\begin{array}{c}32.22 \\
(34.56)\end{array}$ & $\begin{array}{r}42.96 \\
(40.93)\end{array}$ \\
\hline $\mathbf{T}_{\mathbf{5}}$ & $\begin{array}{l}\mathrm{T}_{1}+\text { Two foliar spray of Folicure @ } \\
0.1 \% \text { (one at boot leaf stage and second } \\
\text { after } 20 \text { days) }\end{array}$ & $\begin{array}{c}12.96 \\
(21.08)\end{array}$ & $\begin{array}{c}30.93 \\
(33.76)\end{array}$ & $\begin{array}{r}41.30 \\
(39.96)\end{array}$ \\
\hline $\mathbf{T}_{6}$ & $\begin{array}{l}\mathrm{T}_{1}+\text { Two foliar spray of Nativo @ } \\
0.4 \% \text { (one at boot leaf stage and second } \\
\text { after } 20 \text { days) }\end{array}$ & $\begin{array}{c}13.15 \\
(21.25)\end{array}$ & $\begin{array}{c}35.74 \\
(36.69)\end{array}$ & $\begin{array}{c}48.52 \\
(44.13)\end{array}$ \\
\hline $\mathbf{T}_{7}$ & $\begin{array}{l}\mathrm{T}_{2}+\text { Two foliar spray of Propiconazole } \\
\text { @ } 0.1 \% \text { (one at boot leaf stage and } \\
\text { second after } 20 \text { days) }\end{array}$ & $\begin{array}{c}9.26 \\
(17.70)\end{array}$ & $\begin{array}{c}21.67 \\
(27.72)\end{array}$ & $\begin{array}{c}32.96 \\
(35.02)\end{array}$ \\
\hline $\mathbf{T}_{8}$ & $\begin{array}{l}\mathrm{T}_{2}+\text { Two foliar spray of Hexaconazole } \\
\text { @ } 0.1 \% \text { (one at boot leaf stage and } \\
\text { second after } 20 \text { days) }\end{array}$ & $\begin{array}{c}9.44 \\
(17.88)\end{array}$ & $\begin{array}{c}26.48 \\
(30.95)\end{array}$ & $\begin{array}{r}37.59 \\
(37.79)\end{array}$ \\
\hline $\mathbf{T}_{9}$ & $\begin{array}{l}\mathrm{T}_{2}+\text { Two foliar spray of Folicure @ } \\
0.1 \% \text { (one at boot leaf stage and second } \\
\text { after } 20 \text { days) }\end{array}$ & $\begin{array}{c}9.07 \\
(17.52)\end{array}$ & $\begin{array}{c}25.00 \\
(29.98)\end{array}$ & $\begin{array}{r}35.93 \\
(36.81)\end{array}$ \\
\hline $\mathbf{T}_{10}$ & $\begin{array}{l}\mathrm{T}_{2}+\text { Two foliar spray of Nativo @ } \\
0.1 \% \text { (one at boot leaf stage and second } \\
\text { after } 20 \text { days) }\end{array}$ & $\begin{array}{c}9.44 \\
(17.87)\end{array}$ & $\begin{array}{c}33.89 \\
(35.58)\end{array}$ & $\begin{array}{c}44.81 \\
(42.00)\end{array}$ \\
\hline$T_{11}$ & Untreated/ Control & $\begin{array}{c}22.22 \\
(28.11)\end{array}$ & $\begin{array}{c}52.59 \\
(46.46)\end{array}$ & $\begin{array}{r}76.48 \\
(60.96)\end{array}$ \\
\hline SEm \pm & & 0.32 & 0.38 & 0.47 \\
\hline CD@ 5\% & & 0.96 & 1.15 & 1.42 \\
\hline
\end{tabular}

*Figures given in parenthesis are transformed value.

*All the values are average of three replications. 
Table.2 Effect of fungicides and bio-agent on 1000 grain weight, yield $\mathrm{qha}^{-1}$, percent increase yield and avoidable yield loss against spot blotch of wheat

\begin{tabular}{|c|c|c|c|c|}
\hline Treatments & $\begin{array}{c}\text { Thousand grain } \\
\text { weight (g.) }\end{array}$ & Yield (q/ha) & $\begin{array}{c}\text { Per cent increase } \\
\text { yield }\end{array}$ & $\begin{array}{c}\text { Avoidable yield loss } \\
(\%)\end{array}$ \\
\hline $\mathbf{T}_{1}$ & $\begin{array}{c}36.29 \\
(37.02)\end{array}$ & $\begin{array}{c}32.46 \\
(34.71)\end{array}$ & 4.27 & 4.09 \\
\hline $\mathbf{T}_{2}$ & $\begin{array}{c}36.94 \\
(37.41)\end{array}$ & $\begin{array}{c}33.99 \\
(35.65)\end{array}$ & 9.18 & 8.41 \\
\hline $\mathbf{T}_{3}$ & $\begin{array}{c}39.46 \\
(38.90)\end{array}$ & $\begin{array}{c}37.13 \\
(37.52)\end{array}$ & 19.27 & 16.15 \\
\hline $\mathbf{T}_{4}$ & $\begin{array}{c}38.56 \\
(38.37)\end{array}$ & $\begin{array}{c}36.20 \\
(36.97)\end{array}$ & 16.28 & 14.00 \\
\hline $\mathbf{T}_{5}$ & $\begin{array}{c}38.84 \\
(38.53)\end{array}$ & $\begin{array}{c}36.66 \\
(37.24)\end{array}$ & 17.76 & 15.08 \\
\hline $\mathbf{T}_{6}$ & $\begin{array}{c}37.65 \\
(37.83)\end{array}$ & $\begin{array}{c}34.72 \\
(36.08)\end{array}$ & 11.53 & 10.33 \\
\hline $\mathbf{T}_{7}$ & $\begin{array}{c}41.52 \\
(40.10)\end{array}$ & $\begin{array}{c}38.58 \\
(38.38)\end{array}$ & 23.93 & 19.31 \\
\hline $\mathbf{T}_{8}$ & $\begin{array}{c}39.77 \\
(39.08)\end{array}$ & $\begin{array}{c}37.36 \\
(37.66)\end{array}$ & 20.01 & 16.67 \\
\hline $\mathbf{T}_{9}$ & $\begin{array}{c}40.13 \\
(39.29)\end{array}$ & $\begin{array}{c}37.75 \\
(37.89)\end{array}$ & 21.26 & 17.53 \\
\hline $\mathbf{T}_{10}$ & $\begin{array}{c}38.15 \\
(38.13)\end{array}$ & $\begin{array}{c}35.63 \\
(36.63)\end{array}$ & 14.45 & 12.62 \\
\hline $\mathbf{T}_{11}$ & $\begin{array}{c}35.40 \\
(36.49)\end{array}$ & $\begin{array}{c}31.13 \\
(33.90)\end{array}$ & 0.00 & 0.00 \\
\hline SEm \pm & 0.216 & 0.201 & & \\
\hline CD@5\% & 0.641 & 0.597 & & \\
\hline
\end{tabular}

*Figures given in parenthesis are transformed value.

*All the values are average of three replications

Graph.1 Graphic representation showing the effect of fungicides and bio-agent on per-cent disease intensity (PDI) against spot blotch disease of wheat

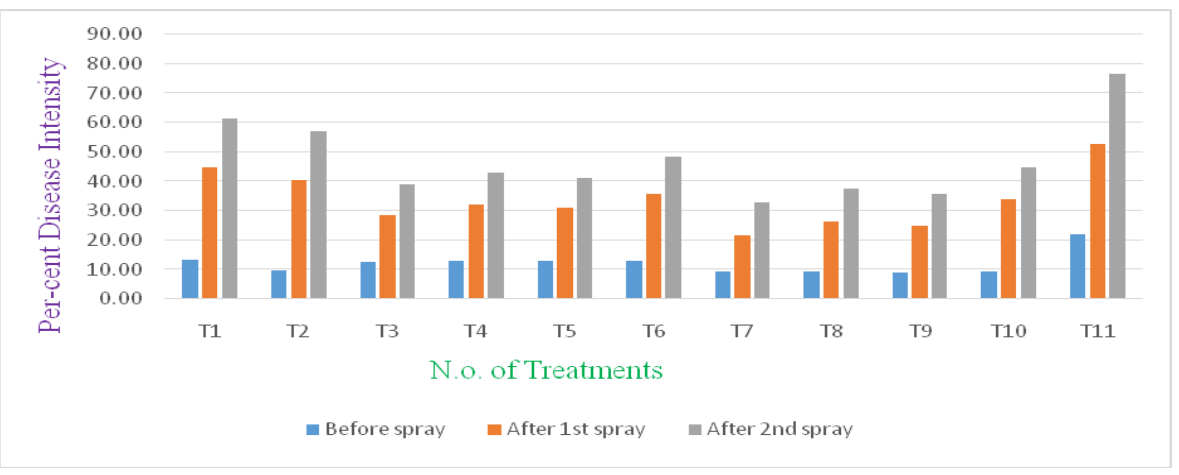


Graph.2 Graphic representation showing the effect of disease on 1000 grain wt., yield q/ha, percent increase yield and avoidable yield loss against spot blotch of wheat

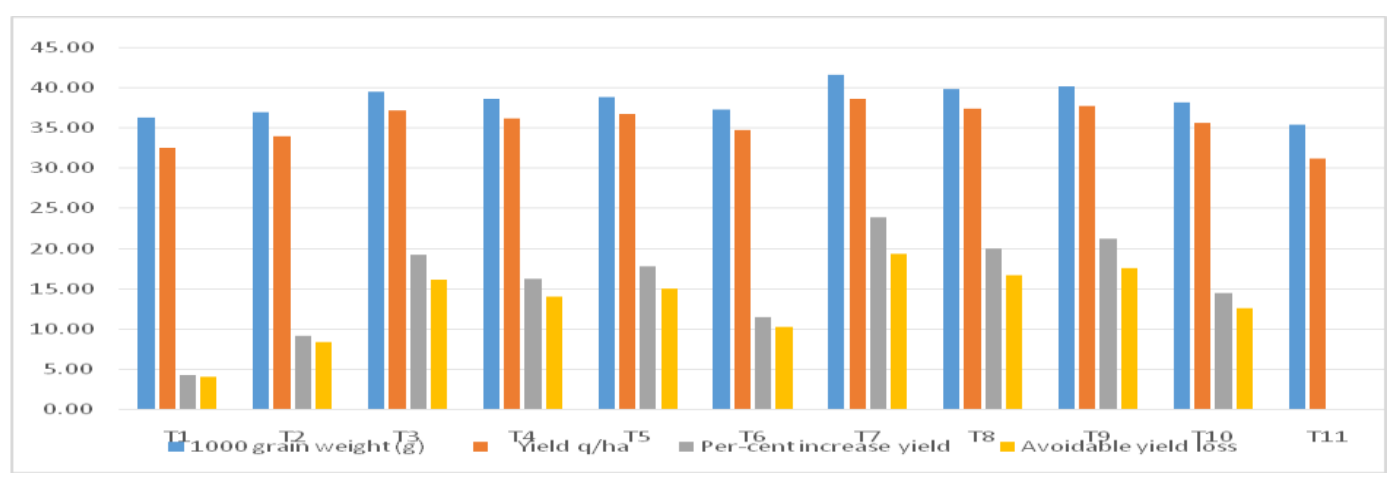

The present findings are collaborate with the findings of Yadav et al., (2015) who tested the effect of recommended dose of fungicides viz.- $\quad$ Propiconazole, Carbedazim, Hexaconazole and two bio-agents i.e. Pseudomonas fluorescence and Trichoderma harzianum and botanicals on incidence and severity of spot blotch disease and seed yield of wheat. The two sprays of Carbendazim $0.1 \%$ at tillering and boot leaf stage resulted in the maximum reduction in spot blotch incidence and severity followed by two applications of Propiconazole at tillering and boot leaf stage. Propiconazole was also found to be quite effective in reducing the level of disease and enhancing crop yield followed by Carbendazim and Hexaconazole. However, Carbendazim, Propiconazole and Hexaconazole were almost equally effective against spot blotch of wheat and may be used as an alternative to each other for management of the disease.Sharma et al., (2005) found Vitavax 200B and Tilt-25 EC more effective for reducing the Helminthosporium leaf blight. Malik et al.,(2008). obtained the varying degrees of severity of spot blotch using the foliar sprays of Propiconazole (Tilt 25\% EC) at different growth stages in the susceptible wheat variety HD 2329, and estimated the losses in yield under different levels of the disease. The yield of protected plots increased significantly as compared to unprotected plots. The increase in yield due to fungicidal spraying over unprotected plots was 29.6, 50.2, 61.2 and 63.4 percent respectively.

\section{Acknowledgments}

I want to acknowledge special thanks to Mr. J.P. Srivastava sir for providing all essential things to carry out my research work and I am also thankful to my colleagues Mr. Vinay Kumar Varma and Mr. Amit Kumar Patel for their valuable suggestion during the research work.

The graph 01 shows the maximum and minimum percent disease intensity at before, after $1^{\text {st }}$ and after $2^{\text {nd }}$ spray of fungicides of each treatment. While the graph 2 indicates the maximum and minimum 1000 grain weight $(\mathrm{g})$, yield $\mathrm{q} / \mathrm{ha}$, percent increase yield and avoidable yield loss of each treatment after harvesting of the crop.

\section{References}

AL-Jiouri, H.A., Miller, P.A. and Robinson, H.F.(1958). Genotypic and environment variance and covariance in an upland cotton cross of inter specific origin. 
Agron. j.,50:633-636.

Chand, R., Pandey, S.P., Singh, H.V., Kumar, S. and Joshi, A.K. (2003): Variability and its probable cause in natural populations of spot blotch pathogen Bipolaris sorokiniana of wheat ( $T$. aestivum L.) in India. Journal Plant Disease Protection, 110: 27-35.

DES, MoA \& FW, India (2017) Department of economics and statistics, ministry of agriculture and farmers welfare.

Gangawane, L.V. (1997). Management of fungicide resistance in Plant Pathogen. Indian Phytopathology,50: 305-313.

Joshi, A.K., Chand, R. and Arun, B. (2002) Relationship of plant height and days to maturity with resistance to spot blotch in wheat. Euphytica, 123: 221-228.

Joshi, A.K., Ortiz-ferrara, G., Crossa, J., Singh, G., Alvarado, G., Bhatta, M.R., Duveillar, E., Sharma, R.C., Pandit, D.B., Siddique, A.B., Das, S.Y., Sharma, R.N. and Chand, R. (2007): Associations of environments in south Asia based on spot blotch disease of wheat caused by Cochliobolus sativus. Crop Science, 47: 1071- 1081.

Kumar, J., Singh, G. and Nagarajan, S. (1998). A field scale of leaf blight recording. Indian Wheat News Newsletter, 5(2): pp 3-4.

Kumar, A., Solanki, I.S. and Kumari, S. (2014). Management of foliar bight (spot blotch) of wheat the most threatening disease of north eastern plain zone (NEPZ) through chemicals. Journal of Agroecology and Natural Resource Management,(1) 1: 4-6.

Mehta, Y.R. (1993). Spot blotch. In: Mathur SB, Cunfer BM (eds.) Seed borne disease and seed health testing of wheat. Copenhagen, Denmark, Jordhurgs forlaget, 105-112.

Malik, V.K., Singh, D.P. and Panwar, M.S.,
(2008). Management of spot blotch of wheat (Triticum aestivum) caused by Bipolaris sorokiniana using foliar spray of botanicals and fungicides. Indian Journal of Agricultural Sciences,78: 646-648.

Sharma-Poudyal D, Duveiller E, Sharma RC (2005) Effects of seed treatment and foliar fungicides on Helminthosporium Leaf Blight and performance of wheat in warmer growing conditions. $J$. Phytopathol, 153:401-408.

Singh,D.V. and Srivastava, K.D. (1997). Foliar blights and Fusarium scab of Wheat. Present status and strategies for management. In: Management of Threatening Plant Diseases of National Importance. Malhotra Publishing House, New Delhi. pp. 1-16.

Viedma, de L. and Kohli M.M.(1998). Spot blotch and tan spot of wheat in Paraguay. In: Duveiller E, Dubin HJ, Reeves J, McNab A (eds.) Proc. Int. Helminthosporium Diseases of wheat: Spot Blotch and Tan Spot. 9-14 1997,CIMMYT, El Batan Mexico, DF, 126- 133.

Yadav, B., Singh, R. and Kumar, A.(2015). Management of spot blotch of wheat using Fungicides, Bio-agents and Botanicals,Department of Plant Pathology,Afri. J. Agril. Rese,10(25), 2494-2500.

Yadawad, A., Hanchinal, R.R., Nadaf, H.L., Desai, S.A., Birader, S. and Naik, V.R. (2015).Genetic variability for yield parameters and rust resistance in $\mathrm{F}_{2}$ population of wheat (Triticum aestivum L.). The Bioscan, 10(2): 707-710.

Zadoks,J.C., Chang, T.T. and Konzak, C.F. (1974). A decimal code the growth stages of cereals. Weed Research,14: 415-421. 


\section{How to cite this article:}

Shiv Shankar Patel, Shiv Pratap Singh, Sandeep Kumar, Ashwani Kumar Patel and Digvijay Singh. 2021. Invivo Management of Spot Blotch (Bipolaris sorokiniana) of Wheat (Triticum aestivum L.), using Bio-Agent and Fungicides. Int.J.Curr.Microbiol.App.Sci. 10(01): 33393346. doi: https://doi.org/10.20546/ijcmas.2021.1001.392 